\title{
SYNONYMY OF PSEUDOBERIS ENDERLEIN WITH NOTHOMYIA LOEW, WITH NOTES ON THE GENUS AND A KEY TO THE SOUTH AMERICAN SPECIES (DIPTERA: STRATIOMYIDAE)*
}

\author{
By Norman E. Woodley \\ Systematic Entomology Laboratory, IIBIII \\ Agricultural Research Service, USDA \\ c/o U. S. National Museum of Natural History \\ Washington, DC 20560
}

Pseudoberis Enderlein (1921: 227) was erected for a single specimen of a new species, P. fallax Enderlein, from Brazil. The species is still known only from the unique holotype. Enderlein believed that, despite its "habitus gleicht sie auffälig Beris Latr.", the genus was related to Chloromelas Enderlein, and placed it in the tribe Stratiomyiini of the subfamily Stratiomyiinae. Unfortunately, the genus and the publication within which it was described were overlooked by James (1973), and the taxon has remained unknown to subsequent authors. I have recently examined Enderlein's holotype, which has resulted in proper taxonomic placement of this taxon.

\section{Genus Nothomyia Loew}

Nothomyia Loew, 1869: 4. Type-species: N. scutellata Loew, by designation of Brauer, 1882: 88.

Pseudoheris Enderlein, 1921: 227. Type-species: P. fallax Enderlein, by original designation. NEW SYNONYMY.

Berisargus Lindner, 1933: 201. Type-species: B. horgmeieri Lindner, by monotypy.

Remarks. Pseudoberis clearly belongs within the tribe Prosopochrysini as defined by James (1942, as Myxosargini), which is placed in the Stratiomyinae by most authors. Important character states, which are exhibited by all members of the tribe, include a generally slender body form, antennal flagellum with six flagellomeres, scutellum usually with two apical spines, crossvein $\mathrm{m}-\mathrm{cu}$

*Manuscript received by the editor Octoher 9, 1984. 
present, vein $A_{1}$ slightly though distinctly sinuate, vein $\mathrm{Cu} \mathrm{A}_{1}$ distinctly, recurvedly arcuate, and female cercus one-segmented. The character states for veins $A_{1}$ and $\mathrm{Cu}_{1}$ are apparently autapomorphic for the tribe, and I personally feel that the second of these is most convincing. The one-segmented female cercus may also be autapomorphic for the Prosopochrysini, although a similar character state is found in other stratiomyids. Nagatomi (1981) included Euparyphus Gerstaecker, Brachycara Thomson, Nemotelus Geoffroy, and Oxycera Meigen in the "Prosopochrysinae" primarily because they have one-segmented female cerci. I believe the placement of these genera requires further documentation before this can be accepted, as all of those genera have vein $\mathrm{Cu}_{1}$ virtually straight or curved slightly toward the apex of the wing. Based on examination of specimens and figures associated with original descriptions, I believe the following genera can be placed in the Prosopochrysini with some certainty: Acanthasargus White, Hoplistopsis James, Melanochroa Röder, Myxosargus Brauer, Nothomyia Loew, Prosopochrysa De Meijere, and Rhaphiocerina Lindner. Cyphoprosopa James (1975: 473, 474, Figs. 1, 2) may also belong here, but James' figure of its wing indicates that vein $\mathrm{CuA}_{1}$ is straight.

Pseudoberis is here synonymized with Nothomyia because $P$ fallax is so similar to other Brazilian species placed in the genus Nothomyia (see below). The genera within the tribe are not well defined, and are badly in need of reevaluation at the world level. Nothomyia is primarily found in the New World and is separated from Myxosargus on the basis of its slender sixth antennal flagellomere, which ranges from elongate conical (as in Fig. 1) to aristate. This flagellomere is not slender in Myxosargus. Melanochroa, the third New World genus in the tribe, has an aristate antennal flagellum, but the eyes are dichoptic in males, while they are holoptic in Nothomyia. Nothomyia purportedly occurs in the Old World, but Prosopochrysa (another Old World genus in the tribe) is so similar that these species ( $N$. bicolor Hollis, Java; $N$. brevis (Bigot), New Caledonia) cannot be considered members of Nothomyia with certainty. At present, no apomorphic character state is known which may be used to unambiguously define Nothomyia.

The South American species placed in Nothomyia exhibit more variation in the shape of the antennal flagellum than do members of the genus occurring elsewhere. The sixth flagellomere ranges from rather thickened and style like (as in Fig. 1) to aristate in the five 
known species from Brazil. Caribbean and Central American species all have the sixth antennal flagellomere strongly aristate. In this regard, the South American species are somewhat intermediate between more typical members of Nothomyia, as exemplified by the type-species ( $N$. scutellata Loew, from Cuba), and species of Myxosargus. This further indicates the need for reevaluation of generic concepts within the tribe.

\section{Nothomyia fallax (Enderlein), NEW COMBINATION}

Pseudoberis fallax Enderlein, 1921: 277.

Type material. The holotype male is housed in the Zoologisches Museum der Humboldt-Universität, Berlin, East Germany. It is labeled: "Brasilien/9368/[purple square]/Coll. H. Loew/Type/ Pseudoberis fallax Type Ender. $\hat{o}$ Dr. Enderlein det. 1919/Beris (Nov gen) eupoda $\mathrm{m} /$ Nothomyia fallax (Enderlein) Det. N. E. Woodley 1982". The specimen is in excellent condition. The genitalia are preserved in glycerin in a microvial attached to the pin of the specimen.

Description. Male. Head (Fig. 1) black, with faint bronzy greenish metallic reflections; eyes essentiallly holoptic, separated on upper frons by less than diameter of a single ommatidium, ommatidia not strongly differentiated in size; lower frons widely triangular, slightly convex, sharply impressed medially in lower half; upper frons very narrowly triangular in front of anterior ocellus; ocellar tubercle moderately prominent; face wide, convex, sides divergent toward oral margin, but not produced downward; lower occiput somewhat convex; lower frons with small, tear-drop shaped, silvery white tomentose spots near upper margins which are contiguous with eye margins, and with very narrow margins inconspicuously tomentose, head otherwise not tomentose; head mostly pilose, hairs longest on face where they are about as long as the basal two antennal segments combined, mostly brownish, but whitish lateral to antennae, most of occipital hairs also pale; antennae subequal to head in length, ratio of segments 13:15: 55[7:4:5:6:7:26], first two segments blackish, very narrowly pale apically, with blackish hairs; flagellum gradually tapering to a sharp apex, first three flagellomeres yellowish brown, last three darker brownish; flagellum with velvety vestiture, but the individual hairs quite long and noticeable; palpi small, 

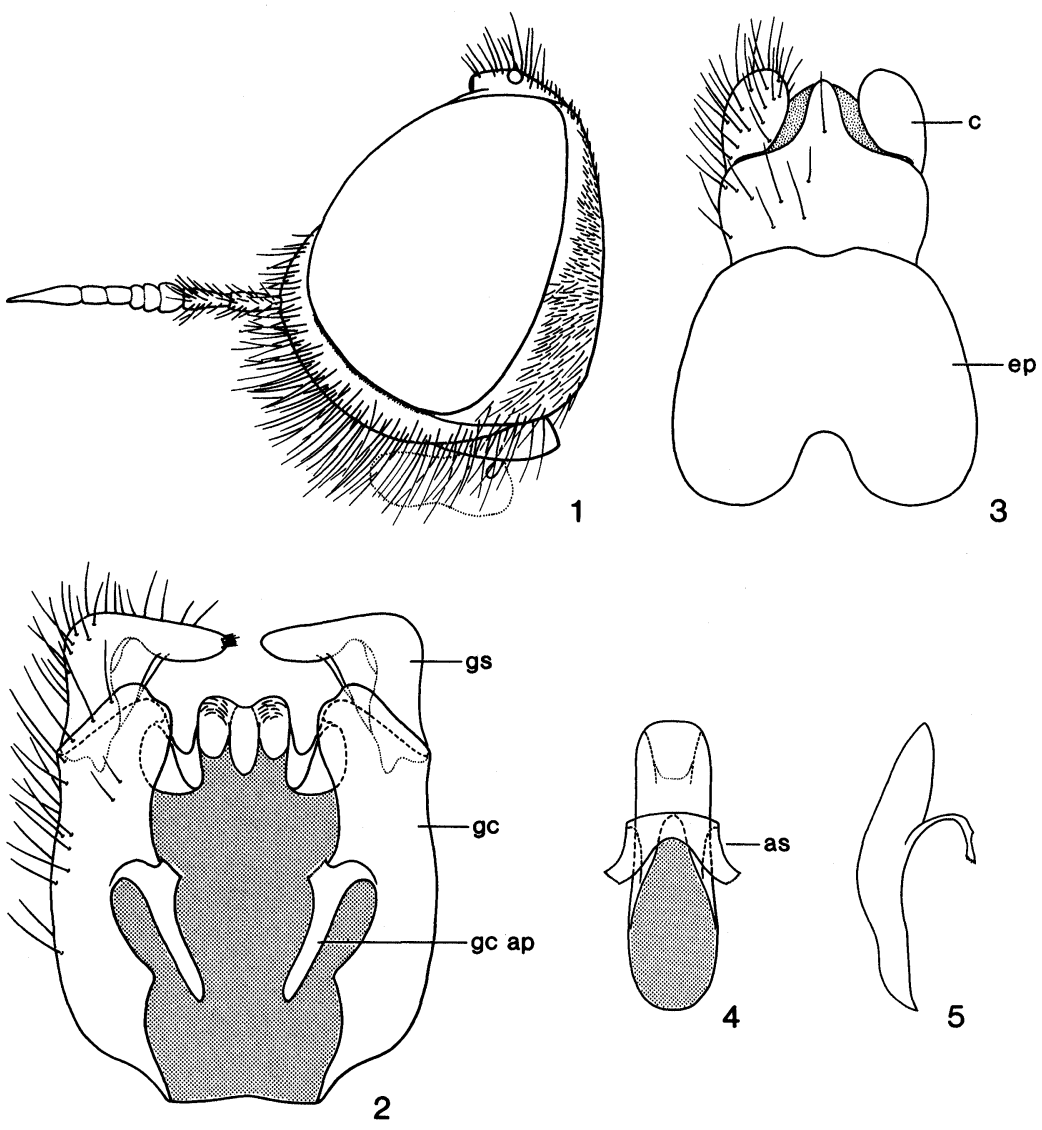

Figs. 1-5. Features of Nothomyia fallax (Enderlein), drawn from the male holotype. 1, left lateral view of head. 2, male genital capsule, dorsal view. 3, post-genital segments, dorsal view. 4, aedeagal complex, dorsal view. 5, aedeagal complex, right lateral view.

Abbreviations: as, attachment structure; $c$, cercus; $e p$, epandrium; $g c$, gonocoxite, gc ap, gonocoxal apodeme; $g s$, gonostylus. 
only one segment visible (probably one-segmented as in other species), blackish, with short dense pale hairs over entire surface; proboscis brownish yellow, with pale hairs.

Thorax with mesonotum blackish, with strong dark greenish metallic reflections, post alar calli slightly brownish, scutellum concolorous with mesonotum, but with two pale yellowish spines; pleura similar to dorsum in coloration, although metallic reflections are less strong, with meron + katepimeron brownish; mesonotum finely rugose, thus only somewhat shiny; scutellum rather short and broad, with apical spines short, directed about $45^{\circ}$ above plane of scutellum; thorax with thin, inconspicuous, grayish tomentosity on prosternum, meron + katepimeron, anatergite, mediotergite, and subscutellum; thorax mostly pilose, hairs longest on mesonotum where longer hairs are about as long as hairs on face, bare on middle part of anepisternum, posterior fourth of anepimeron, all of meron+ katepimeron, subscutellum, and mediotergite; mesonotal and scutellar hairs consist of longer, brownish hairs and short whitish hairs, both types more or less erect, other pilosity uniform and whitish; front legs brownish black, yellowish at extreme apices of femora and bases of tibiae, middle and hind legs similar except that extreme apices of tibiae and entire tarsomeres one to three are pale yellowish; pilosity of legs mostly short, longer on posterior surfaces of femora, mostly pale yellowish but brownish on part of front tibiae, most of front tarsi, and last two tarsomeres of middle and hind legs; wing mostly hyaline, apex of cell sc and all of $r_{1}$ brownish, with a brownish spot at apex of $R_{2+3}$ that extends posteriorly through $R_{4+5}$, and with a vague brownish band extending through most of cell cup to middle of $\mathrm{M}_{1}$, apex of wing contrastingly hyaline; most of wing with microtrichia, but basal half of cell behind stem vein and posterior three-fourths of alula bare; $R_{2+3}$ short and straight, $\mathbf{R}_{4}$ absent, $\mathrm{M}_{3}$ present and distinct but evanescent at base.

Abdomen dark brown, without metallic reflections; typical for genus, long and narrow, gradually widening to apex of third segment, then gradually narrowing to the rounded fifth segment; with little tomentosity, thinly present only at sides of first tergite and sternite; dorsal pilosity brownish, short and only semi-erect over most of surface, long and straight laterally, a little longer than on face, sternites with fairly short, mostly yellowish hairs; genitalia with gonocoxites (Fig. 2) somewhat longer than wide, sides nearly 
straight; gonocoxal apodemes short, slender; posterior margin of hypandrium with a short, more or less quadrate process that is complex and membranous in part; gonostylus of moderate size, external margin strongly bent near middle, apex sharply rounded in dorsal view, internal surface invaginated medially; aedeagal complex (Figs. 4, 5) small and simple, only slightly arcuate in profile, aedeagus and aedeagal valves apparently strongly fused, thus the posterior part of the complex consists of a single lobe, with a simple attachment structure; epandrium (Fig. 3) slightly broader than long, only narrowly emarginate on anterior margin, thus almost plate like, rounded, with feeble emargination along posterior margin; cerci short, rounded, only slightly longer than wide. Length $5.3 \mathrm{~mm}$.

Female. Unknown.

Remarks. The following key, compiled mostly from Lindner's original descriptions and figures, will serve to identify all known species of Nothomyia from South America, and will succinctly compare $N$. fallax with them.

\section{Key to South American Nothomyia}

1. Legs extensively yellow; wings brownish gray with three milky white crossbands ........ fasciatipennis (Lindner) Legs mostly blackish, only yellowish on some tarsomeres; wings may be infuscated, but are without distinct crossbands ...................... 2

2. Halter yellowish; last antennal flagellomere very slender, arista like (Lindner, 1935: Fig. 10); $R_{4}$ present or absent . . . 3 Halter dark brownish; last antennal flagellomere thickened basally (Fig. 1; Lindner, 1935: Fig. 11); $\mathbf{R}_{4}$ absent . . 4

3. $\mathrm{R}_{4}$ present $\ldots \ldots \ldots \ldots \ldots \ldots$. longisetosa (Lindner) $\mathrm{R}_{4}$ absent $\ldots \ldots \ldots \ldots \ldots \ldots$. borgmeieri (Lindner)

4. Apex of wing hyaline, contrasting with subapical infuscation; sixth antennal flagellomere of male gradually attenuate toward apex ............ fallax (Enderlein) Apex of wing infuscated, not contrasting in coloration with sub-apical region; sixth antennal flagellomere of male more strongly attenuate, the apical portion very narrow, nearly hair like ............... lopesi (Lindner) 
As can be seen from the above key, Nothomyia fallax is most similar to $N$. lopesi. I have examined two pairs of $N$. lopesi, which had been compared to the type by Lopes. Three of the specimens were from the type locality and were probably collected at the same time as the types. The overall coloration and general appearance of the two species are quite similar, as are the male genitalia. In $N$. lopesi, the apex of the aedeagal complex is slightly more truncate, the gonocoxal apodemes are slightly longer, the apical portion of the gonostylus is very slightly more robust, and the shape of the medial invagination of the gonostylus in slightly different. With so few specimens available, the variability of these slight differences cannot be assessed. It is possible that larger series will render the differences less useful in distinguishing the species.

\section{ACKNOWLEDGEMENTS}

I wish to thank H. Schumann of the Zoologisches Museum der Humboldt-Universität, Berlin, East Germany, for the loan of the holotype of $N$. fallax, and William J. Turner of the James Entomological Collection, Washington State University, Pullman, Washington, for the loan of material of $N$. lopesi. I also am indebted to Wayne N. Mathis, Department of Entomology, Smithsonian Institution, and R. V. Peterson and R. E. White of the Systematic Entomology Laboratory for reviewing the manuscript.

Literature Cited

Bratier, F.

1882. Die Zweiflügler des Kaiserlichen Museums Wien. II. Math.-Nat. Cl. Denkschr. K. Akad. der Wiss. Wien, 44: 59-110.

ENDERLEIN, G.

1921. Dipterologische Studien XVII. Zool. Anz., 52: 219-232. JAMES, M. T.

1942. A review of the Myxosargini (Diptera, Stratiomyidae). Pan-Pacific Ent., 18: 49-60.

1973. Family Stratiomyidae, No. 16. In A catalogue of the Diptera of the Americas south of the United States. Museu de Zoologia, Universidade de São Paulo, São Paulo, 95 pp.

1975. New taxa and records of Stratiomyidae from Madagascar (Diptera). Ann. Ent. Soc. Amer., 68: 473-481.

LINDNER, E.

1933. Zweiter Beitrag zur Kenntnis der sudamerikanischen Stratiomyidenfauna (Dipt.). Rev. Ent., 3: 199-205. 
1935. Dritter Beitrag zur Kenntnis der sudamerikanischen Stratiomyiidenfauna (Dipt.). Rev. Ent., 5: 396-413.

LOEW, $\mathrm{H}$.

1869. Diptera Americae septentrionalis indigena. Centuria octava. Berlin. Ent. Ztschr., 13: 1-52.

Nagatomi, A.

1981. Female terminalia and systematic positions of some Stratiomyidae. Kontyâ, 49 563-576. 

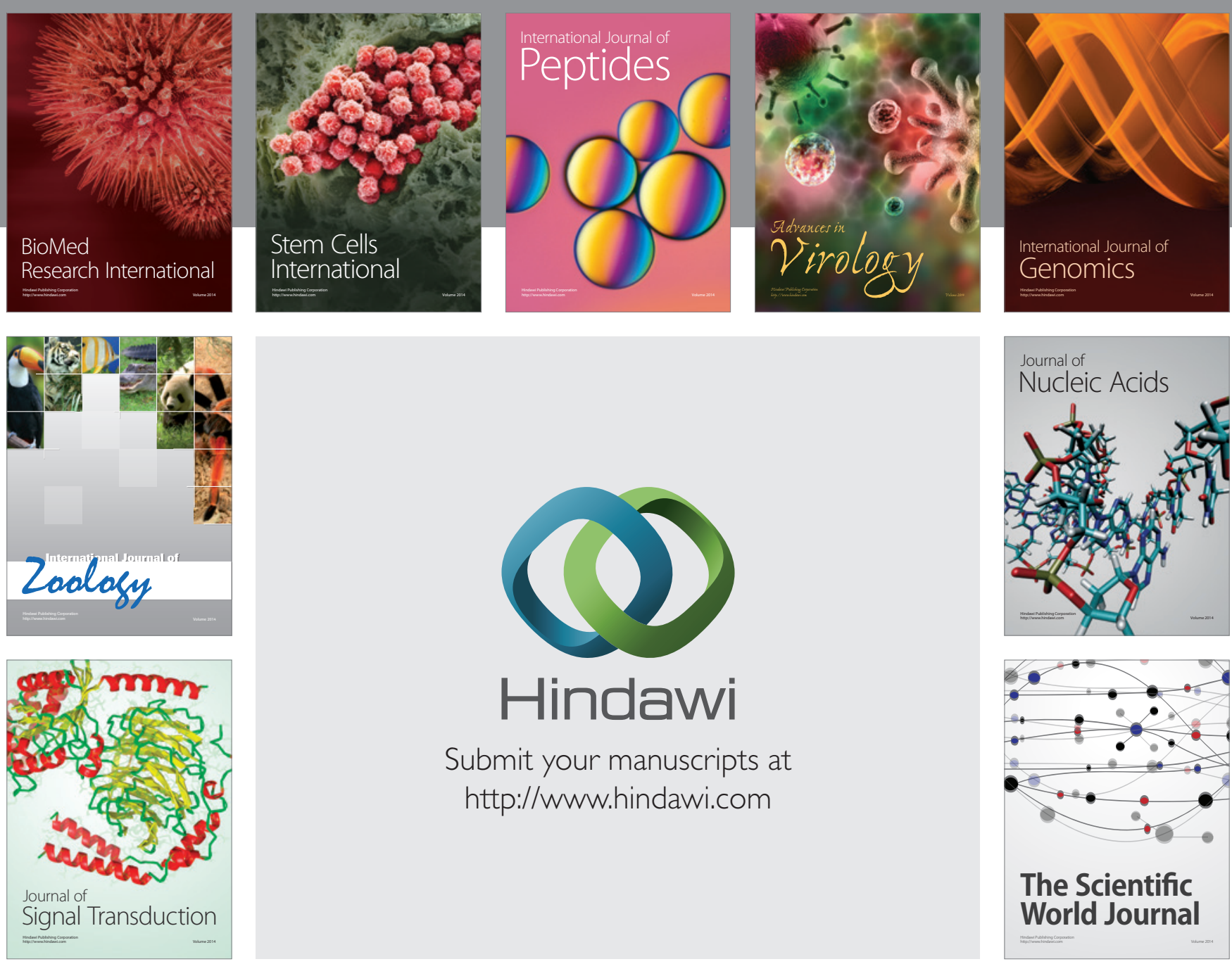

Submit your manuscripts at

http://www.hindawi.com
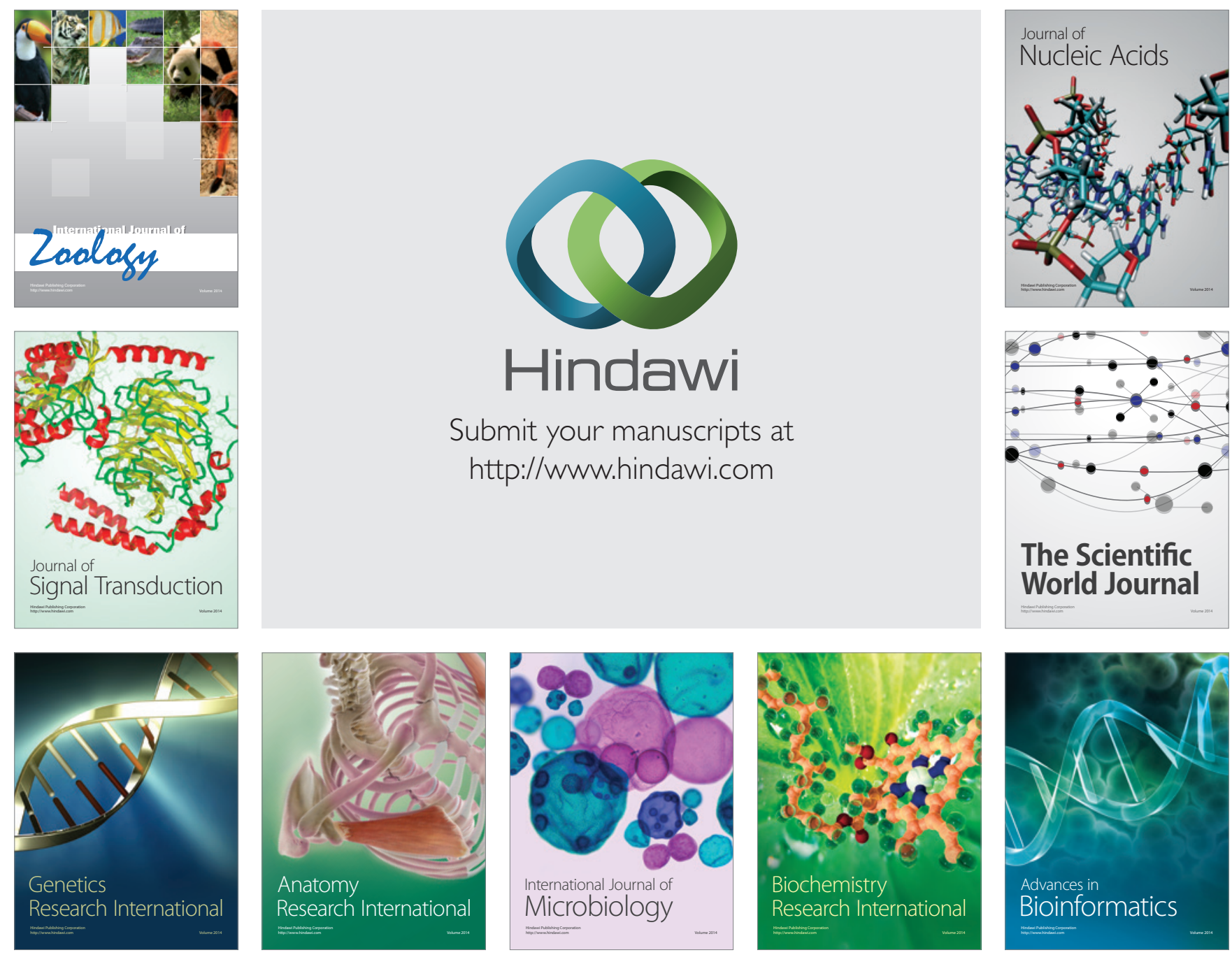

The Scientific World Journal
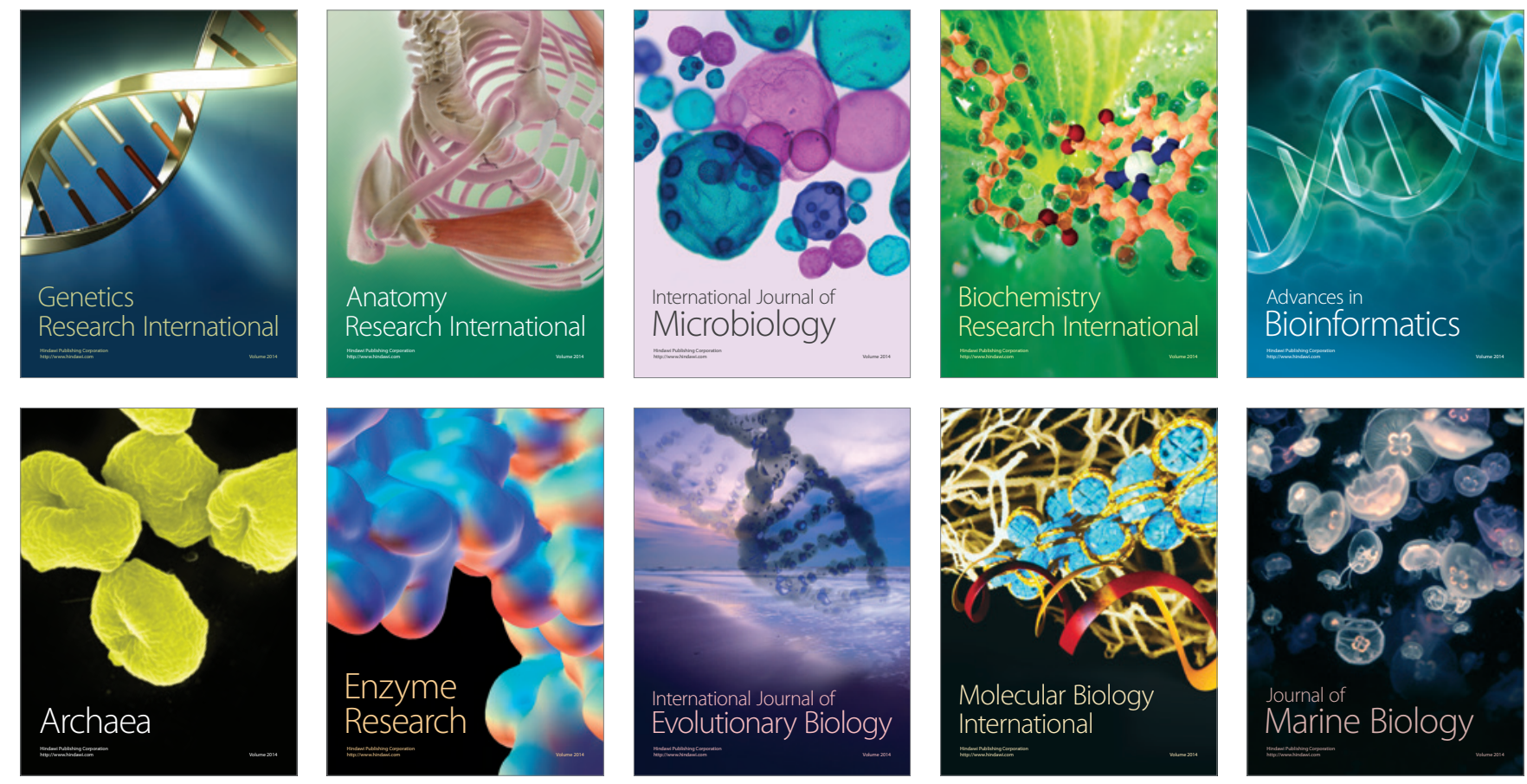